\title{
Surveying relationship between Biorhythm and making error in buying stock in Tehran stock exchange
}

\author{
Soma Aminvaziri* ${ }^{1 *}$ Mansour Irandoost.PH.D ${ }^{2}$ \\ ${ }^{1}$ MSc. Student, Islamic Azad university of Sanandaj, Kurdistan, Iran \\ ${ }^{2}$ Associate Prof, Islamic Azad University of Sanandaj, Kurdistan, Iran \\ *corresponding email: aminvaziri_soma@yahoo.com
}

Keywords: Biorhythm, stock, Emotional, Physical, Intellectual

\begin{abstract}
Biorhythm is defined as any repeated pattern of physical, emotional, and intellectual activities which some believe to affect human's behavior. This article studies relationship between Biorhythm, 3 dimensions of Biorhythm (Emotional, Physical and Intellectual) and making error in buying stock in Tehran stock exchange. Statistical population of the present study includes all stock buyers in stock exchange at 2014 that of these 312 buyers selected randomly as sample. This research is applicable in terms of goal and descriptive from solidarity category in terms of methodology and is survey in terms of collecting data. For research hypothesis test, Phi \& Cramer's test was used because both of indexes are nominal. Results show there is a meaningful relationship between critical manners in Biorhythm (Emotional, Physical and Intellectual) and error in buying stock (the one that should not be bought) in Tehran stock exchange.
\end{abstract}

\section{INTRODUCTION}

Change in daily performance like training and go to parties, health or sickness feeling, solving problems or even, thought discipline or critical moments of life that person see himself in worst or best situation could be summarized in a 3 periodic circular named physical, emotional and mental circular or biorhythm (haghshenas 1999). Due to biorhythm, human life is affected by 3 circular that each one have a stable time period and 3 stage; charge(positive), critical(passing) and discharge(negative). Composing each of these periods and existing stages create different physical, emotional and mental circumstances (O'Conner, 2011). According to biorhythm theory the performance of people is a function of biorhythm periods and composing periods. Principally days that person is at peak of periods, are most successful and favorites ones. Days that are in active stage of curve (half positive), ability is high and days that are in in inactive stage (half negative) are the low energy and disorder ones. When biorhythm curve is about zero line and passing active stage to inactive one, days are most dangerous and critical days (Moldovan et al 2011). Since primary type of biorhythm theory suggested by Fillis till now, many researches fulfilled on different sides of it with contradictory results (Mayer \& Gelen, 2006). In recent years many big companies and factories in west hire employees and allocate tasks due to biorhythm and thought cycle of people (O'Conner and Molly 2011).

There are many studies explaining relationship between thought cycles and cognitive performance. Neil \& Sink (1976), examined daily performance of 3 subject in information computing and reaction times in a 70 day period. Results show that fluctuation in thought and behavior performance is a sinusoidal wave pattern that is in line with thought cycle in biorhythm theory (Although they didn't find relationship between fluctuations and the birthday of people)

In recent decades some researchers like Mayer \& Gelen, (2006) and O'Conner and Molly (2011) noticed affection of thought cycles, cognitive performance and human behavior in financial decision making and believe that from point of modern theories, investors have a different view in financial decision making about risk and price of stocks. These researchers state that many investors 
pay no attention to basic concepts and hypothesis and models of investing and even they have no idea about them.

People always try to spend their saves on buying stocks or government bonds in order to earn more output or overcome financial issues of their own company. But funding in Stock Exchange is effected by different factors so is a risky act. Some of these factors affect investors' decision that is made due to knowledge, interests and experiences. Today many people make funding and buying decision regardless to noticed factors and so experience financial and nonfinancial losses. Therefore paying attention to biorhythm structure when decide to buy a stock may decline decision errors.

\section{BACKGROUND}

The word "Biorhythm" is derived from two Greek words of bios meaning life and rhythmus meaning regular or thought-out motion. In the Oxford dictionary, biorhythm is defined as any repeated pattern of physical, emotional, and intellectual activities which some believe to affect human's behavior (Saket et al,2011). The biorhythm theory has been based on a certain harmony regarding body's physical, emotional, and intellectual cycles. Some of the conducted researches indicate that human's physiologic behaviors can be programmed to be made the most of, if known (Rabiee and Khatamino, 2011). According to biorhythm theory, everyone spend days of life in a regular harmony from birth to death, and their behavioral pattern follows three physical, emotional, and intellectual cycles which start up based on the individual's exact birth date (Sha'bani et al 2013). This theory emerged in Europe in late 19th century, but it was first formed by a Berlin surgeon named William Fleiss (1809-1928) in 1890s somehow different from its 1970 version. In 1890, a German physician named William Fleiss discovered the existence of biorhythm cycles in human body. He carried out a lot of research on his patients' states and discovered the existence of 23-day physical cycles and 28-day emotional cycles in his patients. Alfred Teleshter discovered the 33- day intellectual cycle by studying the powers of learning and thinking and believed that this rhythm is adjusted by spattering of certain glands like thyroid and pineal (McConnell, 1978). In 1904 in a book about biorhythms, Hermann Swoboda (1873-1963) claimed that he discovered 23day and 28-day cycles through researches he had done (Hinze, 1981). This psychology teacher of the University of Vienna claimed that many patients he had been curing of psychological disorders had dreams, beliefs, and projections which seemed to repeat based on a certain regulation. He, later on, claimed that a lot of these patients had suffered from problems like fever, heart attack, or asthma which appeared periodically and whose cycles of occurrence were different from their emotional cycles. Therefore, he inferred that physical disorders happened almost in 23- day cycles and emotional disorders happened in 28-day cycles (McConnell, 1978). Fleiss believed that 23-day physical cycle emerged from muscular tissues and affected physiological activities of the body. It also had effects on body endurance against ailments, physical power, the speed of doing physical activities, strength, stamina, adaptability, and other physiological factors.

Decision is the thought process of selecting a logical choice from the available options. A determination made by directors and/or management as to how, when, where and how much capital will be spent on investment opportunities(Robbins, 1994). The decision often follows research to determine costs and returns for each option. Capital investment decisions also can be called 'capital budgeting' in financial terms (Plunnett, 1996). Capital investment decisions aim includes allotting the capital investment funds of the firm in the most effective manner to make sure that the returns are the best possible returns. Assessing projects as well as the allocation of the capital depends on the project requirements are some of the most crucial capital investment decisions aspects. There might be many different criteria's for choosing the appropriate and right capital investment decision. For e.g., a company might stress on projects that assure for prompt returns while a few other companies might assert on projects which ensure for a growth in the long term. The important aim of capital investment decision is increasing the firms' value by taking on a good project at the perfect time (Jagongo \& Mutswenje, 2014). The power to study as well as take capital investment 
decisions permits an individual as the manager or owner of a particular business to make sure that their resources which are limited are apportioned to the project(s) which would best accomplish their strategically goals (thus they also are at times denoted as strategic capital investment decisions) (Brav et al, 2000). These kinds of decisions could be associated to capital investments decisions like constructing a new factory, dedication towards a new campaign for marketing, acquiring a business or developing or creating a new website. The aim of a business while making capital investment decisions is maximizing the wealth of the shareholder by acquiring assets and yielding profit and to be able to do this, as the owner of your business, you should to be able to find out and determine as to what projects of capital investment would yield a cash flow which is positive and when there are constrained resources, as they generally are in case of start-up or small business or usually for most of the businesses that are facing the credit-crunch, rate the projects in the bases of priority depending on the kind of value they generate (Kadiyala and Rau, 2004).

Investor market behavior derives from psychological principles of decision making to explain why people buy or sell stocks. No matter how much an investor is well informed, has done research, studied deeply about the stock before investing, he also behaves irrational with the fear of loss in the future. This different behavior in the individual investors is caused by various factors which compromise the investor rationality (Brav et al, 2000). An individual investor is one who purchases generally small amounts of securities for his or her own account. Merikas et al, (2003) found that individuals base their stock purchase decisions on; fluctuation in the price index, recent price movement in a firms stock, current economic indicators. Ikenberry et al, (1995) argue that investor underreacting explains the positive long-run abnormal returns following a share repurchase, a conclusion based on the information conveyed by the share repurchase itself. Lack of evidence for a common behavioral explanation bolsters (Fama's, 1998) argument that, on average, investors are unbiased in their response to information. Merikas et al., (2003) adopted a modified questionnaire to analyze factors influencing Greek investor behavior on the Athens Stock Exchange. The results indicated that individuals base their stock purchase decisions on economic criteria combined with other diverse variables.

Dehghan (2008) in a research examined mental factors effecting investing in Stock Exchange that one of this factors is biorhythm. Results show that Biorhythm affects investors' decision. He again studied at 2013 biorhythm manners and its influence on decision quality of managers in investment fund at stocking market. This time the data show that all 3 biorhythm cycle (emotional, intellectual and physical) have a different role in management decision. Iranlo and et al (2007) considered intellectual cycles of biorhythm using cognitive performance. Results show that cognitive performance is not in line with the common 33 day cycle in biorhythm theory. Souatra and Wiyor (2010) in a 15 month study showed that the critical days in people life is the main factor generating accidents in workplace. Katrin \& Solzer(2011) improved that stuffs work due to their own biorhythm, experience less workplace accidents and those that didn't pay attention to this subject, had 30\% more accident during work. 
So in this paper the conceptual model is presented like below shape

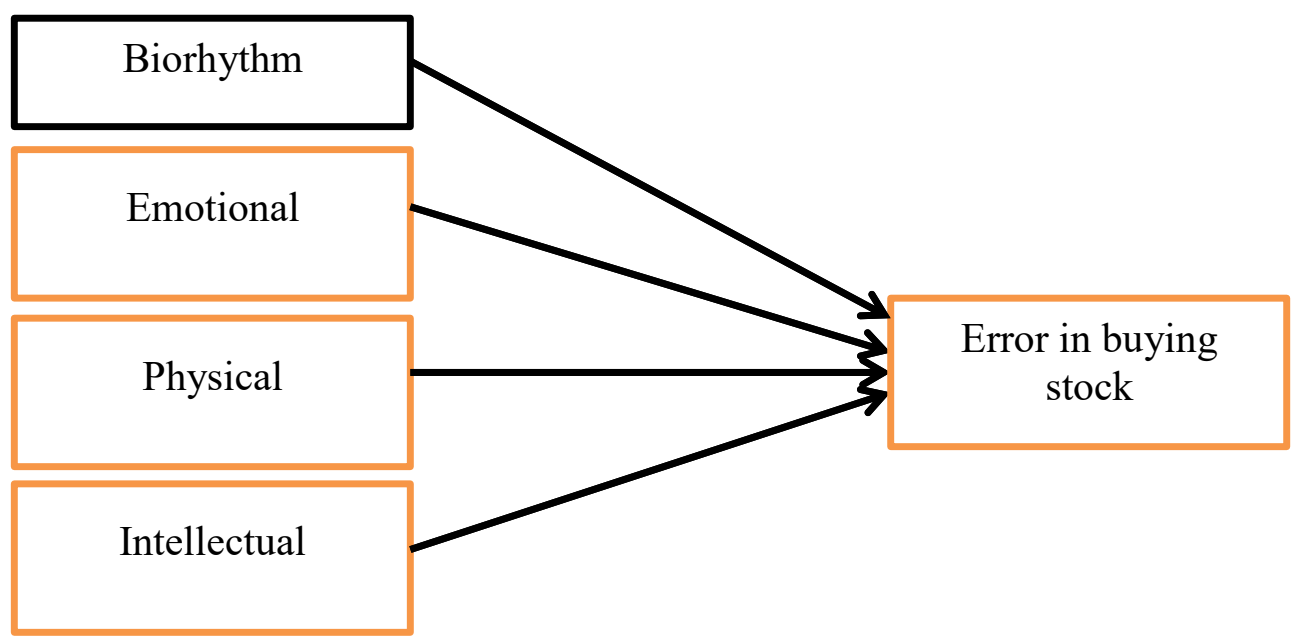

Figure 1: Conceptual model: Dehghan 2008

And present following hypothesis:

There is a meaningful relationship between critical manners in Biorhythm and Error in buying stock (the one that should not be bought) in Tehran stock exchange.

There is a meaningful relationship between critical manners in Emotional Biorhythm and Error in buying stock (the one that should not be bought) in Tehran stock exchange

There is a meaningful relationship between critical manners in Physical Biorhythm and Error in buying stock (the one that should not be bought) in Tehran stock exchange.

There is a meaningful relationship between critical manners in Intellectual Biorhythm and Error in buying stock (the one that should not be bought) in Tehran stock exchange.

\section{METHOD}

Statistical population of the present study includes all stock buyers in Tehran stock exchange at 2014 that of these 312 buyers selected randomly as sample. This research is applicable in terms of goal and descriptive from solidarity category in terms of methodology and is survey in terms of collecting data. To examine the theoretical bases and literature of research, library method and documentary research (books, articles, and periodicals) have been used. A standard questionnaire used for examining error in decision in buying stock and Biorhythm software used for measuring Biorhythm. In the end, the general questions of the demographic were added. To determine the validity of questions a confirmatory factor was used and for reliability Cornbrash's alpha coefficient was used that the results the results showed good reliability and validity of research variables. For research hypothesis test, Phi \& Cramer's test was used because both of indexes are nominal.

\section{RESULTS}

Of 312 selected investors, 300 people are male and just 12 people are female. Over $50 \%$ of them have a academic educational degree and about 52\% of them engaged more than 4 times in buying process. And only $10 \%$ of them engaged less than 2 times. This data confirms the high frequency of engaging in buying stock. 
Table 1 shows Cross tabulation of biorhythm and decision error. As shown in table, error and biorhythm are both a nominal scale with 2 variables. Other dimensions of biorhythm (Emotional, Physical and Intellectual) have a 2 side nominal scale too.

Table 1: Cross tabulation of biorhythm and error

\begin{tabular}{|c|c|c|c|c|}
\hline & & \multicolumn{2}{|c|}{ error } & \multirow[b]{2}{*}{ Total } \\
\hline & & $\begin{array}{l}\text { Purchased stock that } \\
\text { shouldn't be bought }\end{array}$ & $\begin{array}{l}\text { None Purchased stock } \\
\text { that should be bought }\end{array}$ & \\
\hline \multirow{2}{*}{ biorhythm } & noncritical & 74 & 12 & 86 \\
\hline & critical & 161 & 65 & 226 \\
\hline \multirow{2}{*}{ intellectual } & noncritical & 116 & 21 & 137 \\
\hline & critical & 119 & 56 & 175 \\
\hline \multirow{2}{*}{ Emotional } & noncritical & 85 & 44 & 129 \\
\hline & critical & 150 & 33 & 183 \\
\hline \multirow{2}{*}{ Physical } & noncritical & 71 & 36 & 107 \\
\hline & critical & 164 & 41 & 205 \\
\hline
\end{tabular}

Results of table show that 226 investors of 312 that make error (Purchased stock that shouldn't be bought or not purchased stock that should be bought) were in critical time of their biorhythm. This trend is seen in other 3 dimension of biorhythm. For example 119 investor of 312 make error when were in critical time of their intellectual manner and 150 investors for emotional and 164 for physical ones.

Table 2 shows results of Phi \& Cramer's test. As we see, all 4 hypotheses are confirmed because the signification level is less than 0.05 . So we conclude that there is a meaningful relationship between critical manners in Biorhythm (Emotional, Physical and Intellectual)and Error in buying stock (the one that should not be bought) in Tehran stock exchange. In other word, when buyers are in critical days of their biorhythm manners, the possible of making error in buying decision rises.

Table 2: Symmetric Measures

\begin{tabular}{|c|c|c|c|}
\hline \multicolumn{2}{|c|}{ variable } & Value & Approx. Sig. \\
\hline \multirow{2}{*}{ biorhythm } & Phi & .153 & .007 \\
\cline { 2 - 4 } & Cramer's V & .153 & .007 \\
\hline \multirow{2}{*}{ intellectual } & Phi & .192 & .001 \\
\cline { 2 - 4 } & Cramer's V & .192 & .001 \\
\hline \multirow{2}{*}{ Emotional } & Phi & .184 & .001 \\
\cline { 2 - 4 } & Cramer's V & .184 & .001 \\
\hline \multirow{2}{*}{ Physical } & Phi & .150 & .008 \\
\cline { 2 - 4 } & Cramer's V & .150 & .008 \\
\hline
\end{tabular}

\section{CONCLUSION AND RECOMMENDATIONS}

In this article we seek to answer to this question that is there a relationship between critical manners in Biorhythm (Emotional, Physical and Intellectual) and Error in buying stock (the one that should not be bought) in Tehran stock exchange?. In the end it concluded that all relationship confirmed based on Phi \& Cramer's test. The intellectual biorhythm has the greatest relationship 
with making errors (sig is 0.192 ) and Physical biorhythm has the minimum one with sig 0.150 . this results are in line with results of Dehghan (2013) and. Souatra and Wiyor (2010). They confirmed that all 3 biorhythm cycle (emotional, intellectual and physical) have a signification and different role in making error when deciding to buy stocks.

Due to important role of Biorhythm cycle in all managing procedures especially buying stocks that is a critical action in rising or losing firm's profit it is necessary to investors and manager to do some preventive actions. First buyers should always consider their own Biorhythm cycle. This could be done by using online or installed software that can shows cycle and critical times of life monthly. So every buyer could arrange time of buying due to none critical (maximum efficiency of intellectual) days. This process should be monitored and handled by managers so they are sure of the best buying decisions.

From point of managing it's recommended that train buyers and brokers and introduce them the significations of biorhythm not only in business rather in whole life and other practices. Using handbooks or leaflet and developing seminars or workshops within or out of firm are routine ways. Consultation of young managers with more experienced managers for gaining information in field of intuitional decision making and specific service presentation to researchers in field of behavioral researches and comprehensive support from them in direction of implementation of more effective researches in abovementioned fields for making information richer about decision making process are some techniques to refine decision process too.

\section{References}

[1] Brav, A., Geczy, C., \& Gompers, P. A. (2000). Is the abnormal return following equity issuances anomalous? Journal of Financial Economics, 56(2), 209-249.

[2] Dehghan, Abdolmajid.(2008). Physiological factors affecting fund in stock exchange. Political-economic information, 257, 182-91.

[3] Dehghan, Abdolmajid.(2013). Considering Biorhythm Cycle of investors in portfolio construction at Tehran stock exchange. Paper represented in 4th International Conference on Development of Financing System in Iran.

[4] Fama, E., 1998b. Determining the number of priced state variables in the ICAPM. Journal of Financial and Quantitative Analysis 33 (2), 217$\} 231$.

[5] Haghshenas, Mohammad.(1999). What s the biorhythm graph? Tadbir Magazine. 245(25).

[6] Hinze J. (1981)Biorhythm Cycles and Injury Occurrences. Journal of the Construction Division.;107(1):21-33.

[7] Ikenberry, D., Lakonishok, J., Vermaelen, T., 1995. Market underreaction to open market share repurchases. Journal of Financial Economics 39, 181$\} 208$.

[8] Iranlo, Balal; Ebrahimi, Soghra and Habibi, Mojtaba. (2007). Studying validity of intellectual Biorhythm Cycle using cognitive performance. Research in Physiological Health, 3,38-50.

[9] Jagongo, A. O., \& Mutswenje, V. S. (2014). A Survey of the Factors Influencing Investment Decisions: The Case of Individual Investors at the NSE.

[10] Kadiyala,P. and Rau,R. (2004) "Investor reaction to corporate event announcement: Underreaction or overraction?", Journal of Business, Vol.77.

[11] Katrin, L. D. J., \& Sulzer, B. (2011). Increasing industrial safety practices and conditions through posted feedback, Journal of Safety Research, 15(1), 7-21.

[12] Mayer, M., \& Gelen, A. (2006). Birth times: a scientific investigation of the secrets of biorhythm. Sarah Matthews(trans) NY: hill and Wang. 
[13] McConnell JV. (1978)Biorhythms: A report and analysis. Journal of Biological Psychology.;20(1):13-24.

[14] Merilkas,A.,and Prasad,D, (2003), Factors influencing Greek investor behavior on the Athens stock exchange. Journal of Business, Vol.66.

[15] Moldovan E, Enoiu RS, Ruxanda R-A, Leibovici A, Kinetotherapist B. (2011). The Influence of the Human Biorhythm in the Performance Sport Activity. Gymnasium: "Vasile alecsandri" university of bacau.;32(12):34-46.

[16] Neil, D. \& Sink, F. (1976). Laboratory investigation of biorhythms." Aviation, Space, and Environmental Medicine, !2i 425

[17] O'Conner, B. P., \& Molly, K. (1991). Atest of the intellectual cycle of the popular biorhythm theory, J Psych, 125, 294-299

[18] O'Conner, B. P. (2011). The structure \& dynamics of the biorhythm, Sarah Matthews(trans) NY: hill and Wang.

[19] Plunnett.A. (1996)Introduction to management (3th Ed);pws;kent publishing compamany,

[20] Rabiee A, Khatamino F. (2011). Study of the Relationship between Biorhythm and Staff's Job Satisfaction (Case study: Nargan Company). Quarterly Management \& Human Resurces in Oil Industry.;2(8):29-52 [Article in Farsi].

[21] Robbins,O.Stephon; (1994)Essentials of Ordanization Behavior;(4th Ed);prentice Hall International.

[22] Saket RK, Kaushik WCSP, Singh CG. (2011).Biorhythmic Analysis to Prevent Aviation Accidents. In: Jain L, Aidman E, Abeynayake C, editors. Innovations in Defence Support Systems -2: Springer Berlin Heidelberg;. p. 207-40.

[23] Sha'bani Bahar GR, Samadi A, Momeni Piri S. (2013).The relationship between Intellectual and Emotional cycles with respect to Biorhythm Theory and athletes' sport performance. Journal of Sport Psychology Studies.;2(3):13- 28 [Article in Farsi].

[24] Souatra, J. W., \& Wiyor, L. J. (2010). Accident prevention through personnel selection. special issue: recent developments in non-traditional employment testing, Journal of Business and Psychology, 3(2), 187-19. 